九州大学学術情報リポジトリ

Kyushu University Institutional Repository

Species Richness of Galling Arthropods in Brisbane, Green Island, and Daintree National Park in Northeastern Australia

Uechi, Nami

Tokuda, Makoto

Kodoi, Fumio

小土井，文生

https://doi.org/10.5109/2668

出版情報: ESAKIA. 43，pp.11-17，2003-03-31. Entomological Laboratory，Faculty of Agriculture， Kyushu University

バージョン：

権利関係 : 
ESAKIA, (43): 11 - 17. March 31, 2003

\title{
Species Richness of Galling Arthropods in Brisbane, Green Island, and Daintree National Park in Northeastern Australia*
}

\author{
Nami UECHI, Makoto TOKUDA and Fumio KODOI \\ Entomological Laboratory, Graduate School of Bioresource and Bioenvironmental Sciences, \\ Kyushu University, Fukuoka, 812-8581 Japan
}

Daisuke YAMAGUCHI and Junichi YUKAWA

Entomological Laboratory, Faculty of Agriculture, Kyushu University, Fukuoka, 812-8581 Japan

\begin{abstract}
We surveyed the species richness of galling arthropods in northeastern Australia in October 2002 and found 38 sorts of arthropod gall. The gall midge species richness on Eucalyptus spp. may support the microenvironment hypothesis in which the galling habit is considered to be adaptive to dry areas. In Green Island, the species richness of galling arthropods was very poor, since the island is too small and far out at sea. The galling species richness in Daintree National Park was apparently higher than the data recorded by Price et al. (1998) in the places locating on lower latitudes, but was lower than the previous data in Iguassu and Amazon, Brazil. The present data indicates that the species richness of galling arthropods is relatively high both under humid conditions and under high plant species richness in tropical rainforests.
\end{abstract}

Key words: Cecidomyiidae, Eriophyoidea, Psylloidea, microenvironment hypothesis, humid conditions, plant species richness.

\section{Introduction}

The adaptive significance of galling habit by arthropods has been discussed on many occasions. Price et al. (1987) proposed the microenvironment hypothesis and explained that the galling habit has an adaptive significance to dry areas. In addition, Price et al. (1998) emphasized that the species richness of galling arthropods is

\footnotetext{
*Contribution from the Entomological Laboratory, Faculty of Agriculture, Kyushu University, Fukuoka (Ser. 5, No. 93).
} 
relatively high in temperate scleromorphic vegetation. In contrast, Docters van Leeuwen-Reijnvaan \& Docters van Leeuwen (1926) explained the galling species richness in tropical rain forests on the basis of plant species richness. Their explanation has been supported by the field surveys at various places in tropical forests of Indonesia (Yukawa \& Partomihardjo, 1997; Yukawa et al., 2000, 2001a) and in Amazon and Iguassu, Brazil (Yukawa et al., 2001b).

In this study, we examine these two explanations, based on the result of our field survey in subtropical and temperate areas in northeastern Australia.

\section{Materials and Methods}

\section{Census fields}

We surveyed at the following places: Mt. Coot-tha Botanical Gardens, Green Island, and Daintree National Park (Table 1). Mt. Coot-tha Botanical Gardens is $5 \mathrm{~km}$ distant from the Central Business District of Brisbane, which is located in the temperate zone with mild temperatures $\left(30^{\circ} \mathrm{C}\right.$ maximum) and a little rain $(1200 \mathrm{~mm}$ per year) (Commonwealth of Australia, 2000). Green Island (1.6 km in circumference) is one of the small coral islands of the Great Barrier Reef and about $27 \mathrm{~km}$ northeast of Cairns. Daintree National Park is about $82 \mathrm{~km}$ north of Cairns. The climate of Daintree consists of dry and wet seasons. In the dry season (April to December), there is an average of $50 \mathrm{~mm}$ a month of rainfall and in the wet season (January to March), rainfall averages over $400 \mathrm{~mm}$ a month (Commonwealth of Australia, 2003). Rainfall varies throughout Daintree National Park with some parts receiving up to $4000 \mathrm{~mm}$ a year (Commonwealth of Australia, 2003).

\section{Galls and host plants surveyed}

At Mt. Coot-tha Botanical Gardens, we searched intensively for arthropod galls produced on Eucalyptus spp. (Myrtaceae), most of which are native to Australia. On Green Island, arthropod galls were surveyed along a path. In Daintree National Park, we

Table 1. Localities of field survey and the time devoted to finding galls.

\begin{tabular}{|c|c|c|c|c|}
\hline Date & Locality* & Location & $\begin{array}{c}\text { Time } \\
\text { devoted } \\
\text { (minutes) }\end{array}$ & $\begin{array}{c}\text { No. of } \\
\text { persons } \\
\text { engaged }\end{array}$ \\
\hline Oct. 62002 & $\mathrm{CBG}$ & $\mathrm{S} 17^{\circ} 30^{\prime} \mathrm{E} 153^{\circ} 00^{\prime}$ & 30 & 3 \\
\hline Oct. 72002 & GI & S $16^{\circ} 18^{\prime}$ E $145^{\circ} 50^{\prime}$ & 60 & 5 \\
\hline Oct. 82002 & DNP & $\mathrm{S} 16^{\circ} 00^{\prime} \mathrm{E} 145^{\circ} 20^{\prime}$ & 60 & 5 \\
\hline
\end{tabular}

* CBG: Mt. Coot-tha Botanical Gardens, Brisbane; GI: Green Island; DNP: Daintree National Park. 
searched randomly for arthropod galls on various plant species for 60 minutes and recorded the number of galls found every 15 minutes.

We identified galling arthropods based on the shape of galls by the method outlined in Yukawa et al. (2001b). We relied upon the assumptions that each gall morph is unique to a galling arthropod species and that galling arthropod species are specific to a single plant species (following Price et al., 1998). Host plant family or species could not be identified.

In order to adjust the intensity of surveys in Daintree to that of other surveys by Yukawa et al. (2001b), the data was converted to time unit data, 'TUD', the number of sorts of gall found per hour by two persons (following Yukawa et al., 2001b).

\section{Results}

A total of 38 sorts of insect and mite galls were found during the course of our field surveys (Table 2). Among the 38 sorts, 31 were produced by Cecidomyiidae, four by Eriophyoidea, and three by Psylloidea.

Table 2. Sorts of arthropod gall found in each locality.

\begin{tabular}{lrccc}
\hline \multirow{2}{*}{ Galling arthropod } & \multicolumn{4}{c}{ Locality* $^{*}$} \\
\cline { 2 - 5 } & CBG & GI & DNP** & Total \\
\hline Cecidomyiidae & 13 & 2 & $15+(1)$ & 31 \\
Eryophyoidea & 0 & 0 & $3+(1)$ & 4 \\
Psylloidea & 0 & 0 & 3 & 3 \\
\hline Total & 13 & 2 & $21+(2)$ & 38 \\
\hline
\end{tabular}

* CBG: Mt. Coot-tha Botanical Gardens, Brisbane; GI: Green Island; DNP: Daintree National Park.

** Numerals in parenthesis indicate the number of galls that were newly found after four times of 15-minute survey.

Table 3. Number of sorts of galls that were newly found during every 15-minute survey in Daintree National Park.

\begin{tabular}{lclll}
\hline \multirow{2}{*}{ Galling arthropod } & \multicolumn{4}{c}{ Four times of 15-minute survey* } \\
\cline { 2 - 5 } & 1 st & 2nd & 3rd & 4th \\
\hline Cecidomyiidae & 6 & $4+(1)$ & $1+(2)$ & $4+(2)$ \\
Eriophyoidea & 1 & 1 & 0 & 1 \\
Psylloidea & 0 & 1 & 2 & 0 \\
\hline Total & 7 & $6+(1)$ & $3+(2)$ & $5+(2)$ \\
\hline
\end{tabular}

* Numerals in parenthesis indicate the number of the same sorts of galls that were found during the previous 15-minute surveys. 


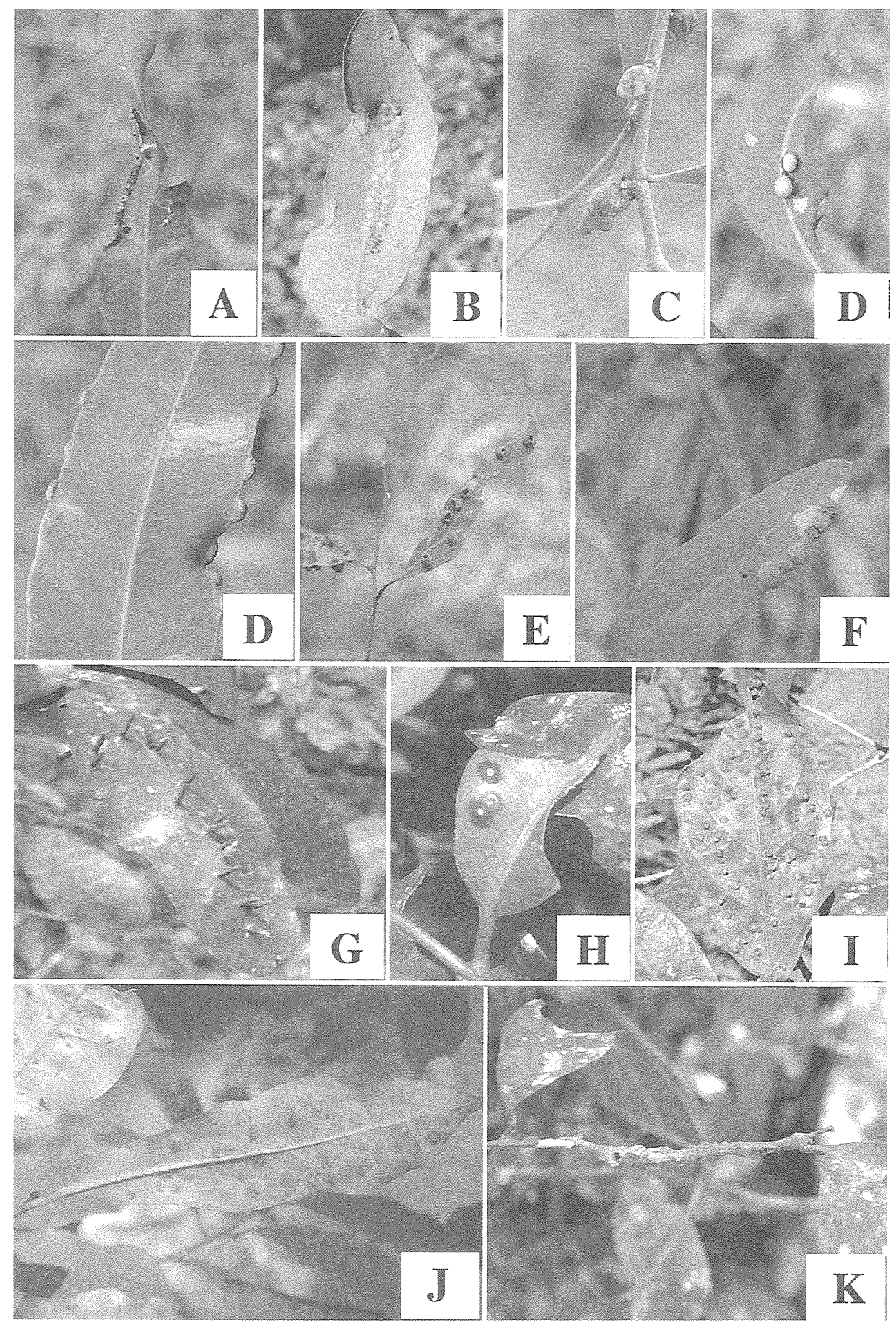

Fig. 1: Galls found in this study. A-F: midge galls on leaves and a leaf bud of Eucalyptus spp. (Myrtaceae) in Mt. Coot-tha Botanical Gardens; G-K: arthropod galls on leaves and a twig of various plant species in Daintree National Park. 
At Mt. Coot-tha Botanical Gardens, all 13 sorts of gall found on Eucalyptus spp. were produced by gall midges (Fig. 1: A-F). In Green Island, only two sorts of galls were found. They were all cecidomyiid galls. In Daintree National Park, we found 15 sorts of cecidomyiid, three of eryophyoid, and three of psylloid galls (Fig. 1: G-K). The TUD in Daintree National Park was 8.4. The number of sorts of galls that were newly found during the last 15 minutes did not decrease tremendously even after three times of 15-minute survey (Table 3). In addition, we found a cecidomyiid and an eryophyoid gall after the 60-minute survey. In total, 23 sorts of arthropod galls were found in Daintree National Park.

\section{Discussion}

At Mt. Coot-tha Botanical Gardens, we found many midge galls on Eucalyptus species. Because Eucalyptus species have adapted to dry areas, the species richness of gall midges on Eucalyptus may support the microenvironment hypothesis (Price et al., 1987). As to gall midge species associated with Eucalyptus, only less than 10 have been described so far (Barnes, 1951; Kolesik, 1995, 1998; Kolesik et al., 2002). Further survey is needed to clarify factors that influence the galling species richness on Eucalyptus spp.

On Green Island, we found only two sorts of midge gall (Table 2). Since this island is too small and far out at sea, colonization, establishment, and maintenance of population seem to be considerably difficult for plants and animals, including galling arthropods as has been pointed out by MacArthur \& Wilson (1967).

At Daintree National Park, we found 21 sorts of gall during the 60 -minute survey. We could find more numerous galls if we devoted more time to searching for galls, because the sorts of gall found every 15 minutes did not overlap too much (Table 3 ). Thus the galling species richness in Daintree National Park was apparently higher than the data recorded by Price et al. (1998) in the places locating on lower latitudes. High plant richness in tropical rainforests has been considered to be an important factor in generating galling arthropod species richness (Docters van Leeuwen-Reijnvaan \& Docters van Leeuwen, 1926; Wright \& Samways, 1998). Our data in Daintree National Park can be also explained by this factor.

However, TUD (8.4) in Daintree National Park was distinctly lower than 17.0 in Iguassu, Argentine side, 23.1 in Rio Paraguquara, Amazon, and 32.0 in Efejeniu Saures, Amazon, although it was almost similar to 9.6 in Iguassu, Brazilian side (Yukawa, 2001b). These data indicate that the galling species richness tend to be relatively high in more humid tropical rain forests in Brazil than in Daintree National Park with dry season. As discussed in Yukawa et al. (2001b), there are several 
examples indicating that the species richness of galling arthropods is relatively high both under humid conditions and under high plant species richness in tropical rainforests. The lower TUD in Daintree National Park than in Brazil may be explained by the combination of these two factors.

\section{Acknowledgements}

We wish to express our cordial thanks to Dr. M. Yamamoto (Kankyo-Kagaku Kabushiki-Gaisha) for his help in the field survey. We thank Dr. O. Tadauchi and Dr. S. Kamitani (Entomological Laboratory, Kyushu University) for their support.

\section{References}

Barnes, H. F., 1951. Gall Midges of Economic Importance. Vol. V: Gall Midges of Trees. 270pp. Crosby Lockwood \& Son Ltd., London.

Commonwealth of Australia, 2000. Climatic Atlas of Australia-Rainfall. 25pp. Bureau of Meteorology, Melbourne.

Commonwealth of Australia, 2003. Detailed Climate Maps. http://www.bom.gov.au/climate/map/annual_rainfall/.

Docters van Leeuwen-Reijnvaan, J. \& W. M. Docters van Leeuwen, 1926. The Zoocecidia of the Netherlands East Indies. 601pp. Batavia-Drukkerij de Unie.

Kolesik, P., 1995. A new species of Eocincticornia Felt (Diptera: Cecidomyiidae) on Eucalyptus fasciculosa in South Australia. J. Aust. Ent. Soc., 34: 147-152.

Kolesik, P., 1998. A new genus and two new species of gall midge (Diptera: Cecidomyiidae) damaging young branches of Eucalyptus spp. in South Australia. Trans. R. Soc. S. Aust., 122: 45-53.

Kolesik, P., G. S. Taylor \& D. S. Kent, 2002. New genus and two new species of gall midge (Diptera: Cecidomyiidae) damaging buds on Eucalyptus in Australia. Aust. J. Ent., 41: 23-29.

MacArthur, R. H. \& E. O. Wilson, 1967. The Theory of Island Biogeography. 203pp. Princeton Univ. Press, Princeton.

Price, P. W., G. W. Fernandes \& G. L. Waring, 1987. Adaptive nature of insect galls. Environ. Entomol., 16: 15-24.

Price, P. W., G. W. Fernandes, A. Christina, F. Lara, J. Brawn, H. Barrios, M. G. Wright, S. P. Ribeiro \& N. Rothcliff, 1998. Global patterns in local number of insect galling species. J. Biogeography, 25: 581-591.

Wright, M. G. \& M. J. Samways, 1998. Insect species richness tracking plant species richness in a diverse flora: galling-insects in the Cape Floristic Region, South 
Africa. Oecologia, 115: 427-433.

Yukawa, J. \& T. Partomihardjo, 1997. Insect and mite galls collected from Peucang, Panaitan, and the Krakatau Islands, Indonesia. Tropics, 7: 141-152.

Yukawa, J., K. Ogata, S. Kamitani, T. Ueno, T. Partomihardjo, S. Kahono \& P. O. Ngakan, 2000. A preliminary report of the field survey in 1999 on Sulawesi Island, Indonesia. Bull. Inst. Trop. Agr., Kyushu Univ., 22: 51-57.

Yukawa, J., K. Ogata, O. Yata, O. Tadauchi, S. Kamitani, S. Helwint, T. Partomihardjo, S. Kahono, P. O. Ngakan \& D. Yamaguchi, 2001a. An interim report of the 2000 survey of entomofauna on Lombok Island, Bali Island, the Krakatau Islands, and in Ujung Kulon, Indonesia. Esakia, (41): 1-10.

Yukawa, J., M. Tokuda, N. Uechi \& S. Sato, 2001b. Species richness of galling arthropods in Manaus, Amazon and the surroundings of the Iguassu falls. Esakia, (41): 11-15. 


$$
\text { - }
$$

